This item was submitted to Loughborough's Research Repository by the author.

Items in Figshare are protected by copyright, with all rights reserved, unless otherwise indicated.

\title{
Organising Greek commercial diplomacy: oscillating between integrated and fragmented models of organisation
}

PLEASE CITE THE PUBLISHED VERSION

https://doi.org/10.1504/IJDIPE.2018.091376

\section{PUBLISHER}

Inderscience

VERSION

AM (Accepted Manuscript)

\section{PUBLISHER STATEMENT}

This work is made available according to the conditions of the Creative Commons Attribution-NonCommercialNoDerivatives 4.0 International (CC BY-NC-ND 4.0) licence. Full details of this licence are available at: https://creativecommons.org/licenses/by-nc-nd/4.0/

\section{LICENCE}

CC BY-NC-ND 4.0

\section{REPOSITORY RECORD}

Georgiadou, Eleni. 2019. "Organising Greek Commercial Diplomacy: Oscillating Between Integrated and Fragmented Models of Organisation”. figshare. https://hdl.handle.net/2134/28071. 


\title{
Organising Greek commercial diplomacy: oscillating between integrated and fragmented models of organisation
}

\begin{abstract}
In a growing number of countries, national diplomatic systems are in a process of profound transformation as a response to the dynamics of globalisation and regionalisation. In this process, a key element of change is that commercial and business activities have become foreign policy priority. In order to pursue this priority effectively, governments of developed economies have integrated commercial diplomacy to their national diplomatic systems by re-arranging their foreign ministries, centralising commercial diplomacy or in some cases merging their foreign ministries and trade/economic ministries. And although literature on commercial diplomacy of competitive economies has found its way into the mainstream of diplomatic studies, there is lack of smaller country based studies with regard to how they choose to organise their commercial diplomacy. Such national accounts of changing diplomatic structures, processes and practices inform well the study of contemporary diplomacy and foreign policy. In this light, this article aims to explore the contemporary organisational setup of commercial diplomacy in Greece. More specifically, it seeks to investigate the structures and processes that Greek governments have put in place for the effective conduct of commercial diplomacy in a globalised world and whether the Greek case is aligned with mainstream developments in the said area of diplomacy.
\end{abstract}

Keywords: commercial diplomacy, economic diplomacy, integrated diplomacy, foreign ministry, business and export support

\section{Introduction}

Economic and commercial diplomacy do not constitute a contemporary phenomenon, however research especially on the latter is recent (Ruël and Zuidem, 2012: 1) and scarce (Kostecki and Olivier Naray, 2007:4). Promoting economic interests has always been a key priority for diplomatic missions (Coolsaet, 2004: 61). For scholars and practitioners of diplomacy alike, the universal recognition that economics lie at the heart of the relations between countries has been reflected through changes in diplomacy since the 1970s (Rana, 2000: 96). In the 1990s commercial diplomacy became central in diplomatic discourse with foreign ministries rediscovering its importance. The reasons for the growing importance of commercial diplomacy are not hard to find. In the face of increasing economic globalisation with its inherent opportunities and threats to the markets, governments of strong industrial states wish to encourage their economic competitiveness overseas and boost their exports. 
The combined effects of the economic crisis in Europe and the impressive rise of new economies, such as the economies of the 'BRICS'1 countries as well as smaller emerging economies, are pushing Western businesses to chase locomotives of global growth through exports and investments. The tectonic shift in the global economy has translated into a strategic pursuit of commercial interests abroad by virtually all Western and most notably European capitals in synergies with governments through channels of commercial diplomacy (Frontini, 2013). In this climate of increasingly export oriented global value chains, it is not surprising that small-sized countries ask the question of whether diplomacy should exclusively focus on commerce in order to survive globalisation (Naray, 2008).

And whilst there is extensive literature on trade and economic diplomacy, far less attention has been devoted to commercial diplomacy (Lee and David Hudson, 2004). This is surprising given that government support for export promotion has intensified over the past couple of decades. Arguably, according to Berrige and Mercier, there is clearly a need for more research on the topic especially in a comparative country case approach (Berrige and James, 2001; Mercier, 2007). Evidently, country focused accounts on the management of commercial diplomacy inform well the study of contemporary diplomacy in terms of practices, processes and structures. This explains why national accounts on the management and organisation of commercial diplomacy have found their way into the mainstream of diplomatic studies. Yet, there is lack of smaller country/economy based studies with regard to the importance they attach to commercial diplomacy and the ways in which they choose to organise it.

Given the need for more country based investigations in commercial diplomacy and the lack of research in this field in the case of Greece, this article explores the organisation of contemporary Greek commercial diplomacy for purposes of contributing to existing literature. With findings that demonstrate alignment of the Greek model of commercial diplomacy organisation with those of developed economies, this paper presents a recent strategic shift in Greek foreign policy making towards policy of economic substance and the prioritisation of supporting Greek entrepreneurship abroad for purposes of boosting Greek exports.

Commercial diplomacy -termed by default economic diplomacy in Greek politicodiplomatic jargon ${ }^{2}$ - was raised at the top of the agenda of the re-organisation of the Ministry of Foreign Affairs (MFA) and its new Charter in 2007 as part of the government's response to demands imposed by economic globalisation (Georgiadou, 2013). The prioritisation of commercial diplomacy in terms of both organisation and function, heralded a shift in Greek foreign policy from 'high politics' towards policy and diplomacy of horizontal economic substance as a result of

\footnotetext{
${ }^{1}$ Brazil, Russia, India, China and South Africa

2 In Greek foreign affairs/diplomacy discussions the term 'economic diplomacy' is used to refer to commercial diplomacy. Based on the above analysis, the usage of the term 'commercial diplomacy' for those aspects of diplomacy explored in the paper is more appropriate and precise
} 
normalization of relations in the post-Cold War era and the development of global and regional cooperation in sectoral and economic policies, especially within the context of the European Union (Karabarbounis, 2007). More specifically, the centralization of the competence of commercial diplomacy in the MFA, heralded a turn towards the strategic promotion of Greek business interests overseas and the crystallization of a governmental agent, i.e. the MFA, as the primary vehicle in this process (Georgiadou, 2013). The changing direction in the MFA's mission towards horizontal economic policies is considered a colossal change which synchronised the entire motor of Greek foreign policy making with globalisation.

Despite the increasing significance attached to commercial diplomacy by Greek governments, the study of Greek commercial diplomacy to date has been lacking context and relevance with regard to the key themes that preoccupy this stream of diplomacy worldwide such as its organisational setup, effectiveness, bureaucratic antagonism and turf wars as well as its impact on the role of diplomat and diplomatic training. Besides, if the organisation of commercial diplomacy is conclusive of the ways in which governments perceive economic globalisation and pursue the promotion of national economic interest, then this study will reflect contemporary Greek perceptions of national interest.

In terms of methodology, this paper investigates the Greek case vis-à-vis the key themes that preoccupy commercial diplomacy research agendas as well as against Rana's four models of organising commercial diplomacy explained below (Rana, 2007). The themes that dominate research in this field involve the ways in which governments choose to organise their bureaucratic structures and processes for the conduct of commercial diplomacy, the responsible ministry and turf wars between more than one ministries. In exploring the Greek case, the article utilises a wealth of evidence generated through a range of primary sources, such as official documentation, governmental websites and interviews with high ranking officials.

Official documentation involves publications such as official government reports, the diplomatic academy's magazine and memoranda (available to the author whilst on fieldwork). In- depth interviews utilising semi-structured open-ended questions were utilised for purposes of generating data to inform the aforementioned areas of enquiry and conducted at various overseas missions. Interviews were held at the MFA's headquarters in Athens and more specifically at the General Directorate for International Economic Relations (DG-B) and the General Directorate for International Development Cooperation (DG-YDAS), at the Economic and Commercial Affairs offices in Brussels and New York and the Economic and Financial Policy Unit of the Permanent Representation of Greece to the EU in Brussels. 


\section{The growing significance of commercial diplomacy}

In the literature, the terms economic and commercial diplomacy are used interchangeably. Even though they both have an overarching economic objective (Potter, 2004), economic diplomacy ${ }^{3}$ is more concerned with international economic issues and uses a full range of instruments (Bayne and Stephen Woolcock, 2003) whereas commercial diplomacy is much more specific (Ruël and Zuidema, 2012). Commercial diplomacy is defined as the application of the tools of diplomacy to help bring about specific commercial gains through promoting exports, attracting inward investment and preserving outward investment opportunities, and encouraging the benefits of technological transfer (Potter, 2004: 55). This does not suggest that economic and commercial diplomacy are separate activities; they are irrevocably intertwined. Essentially, commercial diplomacy is this part of economic diplomacy, which is concerned with economic and commercial policy issues (Berrige and James, 2001: 81). ${ }^{4}$ According to Kostecki and Naray (2007:1), commercial diplomacy is a governmental service to the business community which aims at the development of socially beneficial international business ventures.

Commercial diplomacy is a value-creating activity. By value we mean the utility combination of benefits delivered to the beneficiaries minus the cost of those benefits to business and government with great value-added for its shareholders, that is both businesses and governments (Naray, 2012; Kostecki and Naray, 2007). And although it is hard, to monetise the direct value added of commercial diplomacy empirical research demonstrates that its output is significant for its stakeholders (Zuidema and Ruël, 2012). This is further highlighted in the current economic climate, whereby commercial diplomacy has become even more intriguing. This is because not only does it mitigate market protectionism and government interventionism especially problematic in emerging markets which most Western businesses wish to enter but functions as an accelerator of business internationalisation (Penev at al, 2014). As emerging markets attract Western businesses to venture into unknown territories and display domestic markets with close business-government ties, successful commercial diplomacy becomes instrumental for Western governments and businesses to gain access to these markets (Visser and Ruël, 2014). In their value chain model of commercial

\footnotetext{
${ }^{3}$ More specifically, economic diplomacy embraces the whole spectrum of measures from informal negotiation and cooperation, through soft types of regulation (such as codes of conduct), to the creation and enforcement of binding rules or regimes. In economic diplomacy progress is usually made by persuasion and mutual agreement but in many occasions it can become confrontational and can go right to the brink of conflict.

${ }^{4}$ Olivier Naray, (2008) defines commercial diplomacy as an activity conducted by state representatives with diplomatic status in view of business promotion between a home and a host country. It aims at encouraging business development through a series of business promotion and facilitation activities; Donna Lee in 'The Growing Influence of Business in U.K. Diplomacy', International Studies Perspectives (2004) 5, pp. 50-54: 51, uses a broader definition which encompasses actors outside the traditional governmental diplomatic channels. More specifically, she defines commercial diplomacy as "the work of a network of public and private actors who manage commercial relations using diplomatic channels and processes".
} 
diplomacy Kostecki \& Naray (2007) define a number of commercial diplomacy support activities such as intelligence, networking and public relations, contract negotiations, and problem solving as activities of commercial diplomacy that are beneficial for stakeholders. Those beneficiaries are largely SMEs, micro companies and sole traders who use commercial diplomacy in their first steps of internationalisation in the given target market, where the local commercial diplomat provides market information, list of potential buyers, distributors, importers or simply contacts for more specific information (Ruël, De Boer and Ten Haaf, 2013)

In this light, diplomatic studies literature increasingly emphasises the growing importance attached to commercial diplomacy in the context of its changing practices and organisation as well as the multiplicity of its stakeholders. The value added of commercial diplomacy has been widely acknowledged by governments and has thus become the axis in their pursuit of national foreign policy and diplomacy. Developed and developing countries alike, mobilize their entire diplomatic system in ways that reflect the growing importance of commerce for national economies. In fact, in the era of commerce without borders on which national prosperity depends, commercial advocacy has been raised, for most missions, to their most important and urgent function (US Department report, 1999).

It is not therefore surprising that overseas diplomatic networks are viewed as the ultimate governmental drivers to boosting national economies and commerce and attracting investments in order to contribute to the earnings of national treasuries (Ruël and Zuidema, 2012; Sanders, 2010). In this climate, governments worldwide mandate their diplomatic missions to intensify their business-assistance functions and make commercial diplomacy the epicentre in the reorganisation of their national diplomatic systems (Rana, 2007: 67).

\section{Organising commercial diplomacy: moving towards 'integrated models of diplomacy'}

The impact of increasing economic globalisation and regionalisation on diplomatic services, which now focus on increasing export promotion and inward investment activities, becomes most evident in the structure of foreign ministries, which respond by re-organising themselves along the principle of functionality on top of the traditional principle of territoriality (Lee, 20047: 51). And although there are different national responses with regards to commercial diplomacy arrangements, there are certain themes that dominate the research agenda. Those themes concern changing bureaucratic structures, oscillation of the commercial competence between ministries, transfer of the competence to the MFA and turf wars between more than one ministries (Naray 2008). Many countries, which until recently ran parallel commercial services outside their overseas embassies have 
visualised or already moved towards a model of 'integrated diplomacy' with an 'integrated foreign service' in which the competence of economic and commercial diplomacy is absorbed by the foreign ministry and its diplomatic service (Rana, 2000: 96-97).

Naturally, commercial diplomacy poses challenges not only to foreign ministries but also to diplomatic staff. The business world confronts policy makers and diplomats with new kinds of issues outside the traditional confines of diplomacy (Rana, 2004: 69). Such change has transformed the role and mission of diplomats, by rendering commercial diplomacy one of their substantive tasks. With diplomatic staff being concerned more than ever with a widening range of commercial matters, they now assume a role in business intelligence, partner search, promotion of exports and business advocacy (Naray, 2008). This phenomenon constitutes a major component of integrated diplomacy, which is becoming a trend worldwide (Potter, 2004: 56).

In the face of pressures for more commercial diplomacy and in conjunction with it becoming key foreign policy priority, national governments have been experimenting with a number of strategies in organising this branch of diplomacy. Most competitive economies such as North America, Europe, Southern Africa and Asia have prioritised commercial diplomacy in their foreign policy (Lee and Hudson, 2004: 343). In order to pursue effectively this priority, governments have reformed their foreign ministry and diplomatic service so that they internalise the function of commercial diplomacy. There are about fifteen countries that have merged their ministry of foreign affairs with their ministry of trade to create one consolidated ministry including Australia, Belgium, Canada and Sweden. Countries such as the USA, Germany, UK, Finland, Japan and Singapore have put solid structures in place to promote commercial diplomacy. For instance the UK and the Czech Republic have created a joint body of the ministry of foreign affairs and the ministry of trade in order to strengthen and coordinate export promotion (Rana, 2007: 67-68; Lee and Hudson, 2004: 343).

In addition to revamping the structures for the conduct of commercial diplomacy, governments have also been diversifying diplomatic training. Economics and commerce have become the sine qua non of contemporary diplomatic training. Diplomatic academies have made training on commerce and economics compulsory to their curricula. However, not all diplomatic circles have welcomed the new practices which focus on intense commerce promotion. A number of senior diplomatic staff view the penetration of commerce-centred developments as an attack upon traditional diplomacy. In some Foreign and Commonwealth Office (FCO) quarters, diplomats feel that they are reduced to "selling socks for Britain" that is promoting small business interests rather than negotiating big business deals or political matters- with the diplomatic profession being "a profession in peril" (Lee, 2004: 50). 
Another element that has also had a huge impact on the processes of diplomacy is information technology (IT). The internet has changed the work of diplomats and specifically, in the area of commercial diplomacy it has offered many online ways to facilitate export endeavours (Kurbalija, 1999). By giving access to information about regulations and markets in targeted countries for new investments, IT has become a most valuable tool in the hands of governments and businesses alike to intensify their efforts for more commercial diplomacy.

\section{Models in organising commercial diplomacy: from integration to competition}

And whilst developments calling for more commercial diplomacy have become a key concern for most contemporary states, government responses with regard to its organisation vary. In the literature, Rana (2007) distinguishes five different models in the organisation of commercial diplomacy.

Firstly, there is the 'Unification' model which is essentially an integrationist approach adopted by strong economies such as Australia, Canada and Sweden. In this model the foreign ministry has unified the political and economic/commercial affairs competences. In organisational terms this has been materialised with the addition of a separate commercial/export promotion unit to the traditional diplomatic service and the enhanced unifying role of the head of mission.

Secondly, there is the 'Part unification' model. The best example of this is the UK, which has created two special units in the Foreign and Commonwealth Office jointly with the Department of Trade \& Industry, to handle trade and investments. It is important here that the units are staffed by a unified diplomatic service which embraces both political and economic/commercial functions.

Thirdly, there is the 'Third agency' model, found in Singapore, where the foreign ministry keeps out of economic work and external economic affairs are managed by the Singapore Trade Board and the Singapore Economic Development Board under the supervision of the Ministry of Trade and Industry. Each board dispatches their own representatives at key locations who work closely with diplomatic staff at permanent diplomatic missions.

Fourthly, there is the 'Competition model' which reflects a confused situation in many countries such as India and Thailand where the foreign ministry and economic ministries engage in turf battles over responsibility of export promotion and the handling of World Trade Organisation affairs. The consequence of such battles is that the diplomatic machine does not make a full contribution to advancement of economic and commercial interests.

Finally, there is the 'Renunciation' model where the MFA does not play any role in bilateral economic and commercial affairs and hands over the competence to another ministry such as in the cases of China and Germany. With the 
aforementioned developments in mind the following sections will focus on the Greek case by firstly exploring the ways in which commercial diplomacy is organised and secondly, by relating the Greek approach to contemporary models.

\section{Integrating diplomacy in the MFA: a first step towards a 'Unification' model}

Commercial diplomacy - which until recently in Greece has been understood as a synonym to economic diplomacy ${ }^{5}$ - had been the 'Cinderella' of Greek foreign policy prior to 2000, with its management brushed aside to ministries other than the Ministry of Foreign Affairs (MFA) (Georgiadou, 2013). In early 2000 however, Greek economic and commercial diplomacy acquired new momentum in the circles of the MFA. This momentum was due to a number of reasons. Firstly, the pressures of globalisation on a small economy like Greece brought with it the imperative of internationalisation for small and medium Greek enterprises (SMEs) as well as the need of gaining market shares in third countries. Secondly, Greek governments realised that the national income can be significantly boosted through support of exports and investments (Interview, 10).

Consequently, elevating economic and commercial diplomacy to the top priority of Greek foreign policy became the key objective of the government's strategy to boost the Greek economy via re-deploying and re-arranging the Greek diplomatic capital. In 2007, economic/commercial diplomacy was proclaimed by the Greek government to be the core pillar of Greek foreign policy and thus the pivot in the project of transforming and modernising the MFA and Greek international policy.

The strategy of transforming the MFA, culminating in the 2007 MFA reform Charter (Law 3566/2007, art. 14), aspired to achieve a deep macroscopic and strategic intersection materialized through the re-organization of the MFA to reflect the strategic turn towards economic and commercial diplomacy (Interview 1, Strategic Planning). More specifically, the 2007 Charter, which if not anything else, heralded an unprecedented attitudinal change, aimed at accomplishing the macro-symbiosis of the political and economic diplomatic competences under the aegis of the MFA thus representing a shift in the substance of Greek foreign policy from political to economic. With a renewed, economic mandate, the MFA became the primary governmental vehicle in the management of foreign economic relations and in the promotion of Greek business interests overseas (Bakoyianni, 2009).

\footnotetext{
${ }^{5}$ It is crucial to clarify that with Greece not being in a position where it can use economic resources such as rewards or sanctions internationally in order to promote its foreign policies, the term 'economic diplomacy' becomes rather inappropriate. In reality, the so called Greek economic diplomacy is solely focused on the promotion of exports and trade per se in given loci and therefore, the term commercial diplomacy is more accurate. Therefore, both its substance and organisation focus on commercial diplomacy.
} 
In the course of embracing its new functions and performing its renewed role, the MFA's organisational structure was extended to encompass the competence of foreign economic and commercial diplomacy. Integrating the economic and commercial competence into the MFA's institutional structure marked a strategy to also transform its structure from hierarchical (political) to horizontal/productive (economic) (Karabarbounis, 2007: 200).

The new agenda of Greek commercial diplomacy was largely shaped as a response to the tectonic shifts of global economy and the changing global value chains focused on promoting Greek exports and domestic businesses' internationalisation in emerging markets, attracting foreign investments and intensifying diplomatic and business engagement (Interview 2, CFSP Ministry of Defence). Most importantly, a key priority communicated from the government to all commercial attachés was the intensive support of the booming Greek enterprise in the Balkans manifested from the late 1990s onwards and the systematic pursuit of business enterprise in Africa with a special emphasis on supporting technology related Greek start-ups (Interview 2, Commercial Affairs GrRepEU, 2010).

The function of economic and commercial diplomacy which had been traditionally performed by economic and commercial specialists, graduates of the National School of Public Administration (NSPA) staffed the respective economic and commercial affairs offices (ECOs). ECOs were attached to the network of Greek embassies overseas but before their integration with the MFA in 2002, had constituted a distinct bureaucratic section, accountable to the Ministry of Economy (MNEC). This effectively meant that commercial diplomacy had formed part of the MNEC's mandate and mission until 2002.

The competence of commercial diplomacy, was transferred from the MNEC 6 to the MFA on $1^{\text {st }}$ October 2002. The function was absorbed into the newly formed General Secretariat of International Economic Relations and Development Cooperation at the MFA (Presidential Decree, 159/2002) comprising General Directorate B' Economic Relations and YDAS-Hellenic Aid and presided over by the MFA's General Secretary for International Economic Relations. ${ }^{7}$ In this light, Law $3196 / 2003$ provided that the bureaucratic section of economic and commercial attachés, staffing the Economic and Commercial Offices (ECOs) was to be fully integrated into the institutional structure of the MFA; a change that was crystallised with the 2007 MFA Charter Reform. Four years later, Law 3566/2007 provided for the gradual abolition of both the ECOs office and the NSPA feeding institution and their replacement by MFA diplomatic staff, trained and groomed at the MFA.

\footnotetext{
${ }^{6}$ The competence of economic diplomacy together with the section of economic and commercial attachés previously belonged to the Ministry of Trade.

${ }^{7}$ Alongside the transfer of commercial diplomacy to the MFA another significant institutional development was the centralisation of the Development Cooperation pillar under the aegis of the MFA in the DG YDAS-Hellenic Aid.
} 
Despite enthusiasm on behalf of political leadership over change and adaptation of the Greek foreign policy structures in response to the increasing demands for more efficient and integrated commercial diplomacy, such change was faced with scepticism over the chosen course of action. Yet, Greek officials both at the headquarters in Athens and in overseas missions acknowledged that Greek foreign policy is in a process of 'large scale fermentation' aiming at integrating its economic/commercial and political facets. This fermentation, -which was necessary and long overdue-, indicates the synchronisation of Greek foreign policy with contemporary political and economic developments.

Nonetheless, this process of integrating the political and commercial facets of Greek diplomacy, failed to put an end to the long rooted antagonism between Greek ministries such as the MFA, the NSPA and the MNEC ${ }^{8}$, which battled to gain primacy over economic and commercial diplomacy. Turf wars for control over the commercial function led to a 'reform fever' involving a number of reform proposals and battles over decision making between an enthusiastic MFA political leadership and a resistant NSPA bureaucracy. Evidently, this led to the paralysis of the newly designed commercial function and pathologies in both commercial policy making and traditional political diplomacy (Tsardanidis and Elisavet Mysiri: 2013).

Such battles were mostly due to the abrupt transfer of the commercial function to the MFA's existing structure without any prior institutional adaptation. Not only did the transfer cause organisational conflict between MFA traditional diplomats and newly transferred commercial diplomats but it also resulted in grey areas of competence and jurisdiction at the interface between political and economic diplomacy (Sitaras, 2005). Therefore, integration of the two strands of foreign policy and diplomacy raised concerns and scepticism over its implications for the efficacy of the function of commercial diplomacy and the future of Greek diplomacy.

Strategically, the transfer of the commercial function to the MFA served the government's dual strategic purpose of transforming the MFA into a productive ministry, by enhancing its economic policy-making capacity as well as intensifying commercial activity overseas under the MFA's political and bureaucratic leadership'. 'The rationale of this move was to achieve an osmosis of the political and economic/commercial elements in policy making which represent the two dimensions of foreign policy making capability of Greece. The merging of the two dimensions into a single pillar of representation serves the strategic purpose of enhancing Greek foreign policy making capacity' (Interview 4, Business Development, B8 MFA).

\footnotetext{
${ }^{8}$ And prior to this, in the 1990s, between the MFA and the Ministry of Trade, where the ECOs belonged initially.

${ }^{9}$ The articulation of the strategic target of this assimilation exemplifies again that the substance of the so called foreign economic policy is rather limited to commercial policy
} 
The integration of commercial and political diplomacy was perceived as the optimum way to improve Greek services to citizens and support to businesses engaging in enterprise overseas. The international and domestic financial crises, with the latter posing acute pressures to Greek governments and publics, necessitated more than ever before the boosting of Greek exports and enterprise outside the country for purposes of generating income. Greece has been in an urgent search of a 'force multiplier' and at the same time a 'producer of wealth' to contribute to the national economy back home (Bakoyianni, 2009b).

This urgency had already occurred with the increased demands posed by the process of globalisation and regionalisation. These processes, not only expanded the geographic scope and reach of Greek international engagement but they also brought forward an unprecedented growth in new Greek social, political and most importantly economic interests in areas such as Russia, the Middle East and Asia as well as within the EU and the southern Balkans, thus necessitating increased commercial advocacy overseas. The urgency for increased commercial advocacy and support of Greek enterprise can be exemplified by the programme of 'Go International', an Economic Cooperation Programme jointly run by the Eurobank group with the four Greek Export Associations ${ }^{10}$ under the auspices of the MFA (GoInternational, 2015). In the course of this, the MFA has overseen a total of 6.250 business meetings between 750 participating companies and 356 Greek exporting companies from 2011 to 2013 in the Russian Federation, Romania, Serbia and Cyprus alone.

Therefore, when in 2009, Greek Foreign Minister Bakoyianni stated that 'the integration of commercial diplomacy with the MFA reflects a much needed and unprecedented intersection in Greek diplomacy, which requires change of mentality and close partnership with private businesses with the purpose of providing better goods and services to Greek businesses and publics overseas' (Bakoyianni, 2009b) she reflected the Greek government's transformed conceptualisation of national interest and the respective strategy for re-organising Greek foreign policy altogether. 'Such change, modernizing both the MFA and commercial diplomacy, was aimed at aligning the MFA with strong economies in ways that reflect global trend (Interview 1, Strategic Planning, 2008).

\footnotetext{
${ }^{10}$ Namely, the Panhellenic Exporters' Association, the Greek International Business Association, the Exporters' Association of Crete and SEV Hellenic Federation of Enterprises
} 


\section{The value added of Economic and Commercial Offices}

The network of the $52 \mathrm{ECOs}^{11}$ in 2016 (AGORA portal) attached to the Greek embassies has been a major player in the Greek diplomatic network in countries with a particular economic and commercial interest for Greece. With their role focusing on the systematic monitoring and analysis of economic developments in the host countries and on the consultation and support of those parts of the Greek government and Greek businesses engaging in businesses overseas, these offices have undertaken a very active consultative function and an inter-ministerial coordinating role. The section's main role as described by its staff (Interview 4, Business Development, B8 MFA, 2009) is to:

- monitor the international and local markets in the host country and provide information and guidance to Greek governments and businesses on issues of sectoral significance

- draw a yearly course of action and yearly reports and consult the MFA and the government on issues of foreign economic and commercial policy

- offer guidance, support and coordination to other government departments overseas

- maintain a channel of communication between the HQ and Greek as well as foreign businesses and co-decide over business activity and action plans

- organise exploratory and other business missions to accompany the Prime Minister, the Foreign Minister and his/her deputy or the minister of economy.

The ECOs constitute this part of the Greek international bureaucracy, which arguably altered the dynamics between the overseas missions and the $\mathrm{HQ}$ in that they have undertaken an active role both in policy consultation and formulation. They see themselves as 'the nerve endings of the machinery which sends stimuli back to the centre' whilst at the same time they change previous images of the diplomatic network of being merely an executive tool (Interview 5, Commercial Affairs, COREPER, 2009).

\section{Performance assessment and IT}

Another aspect that contributes to the value added of ECOs is that they transformed significantly the relationship between the MFA and the rest of the Greek public administration in terms of intensifying policy coordination. ${ }^{12}$ This is

\footnotetext{
${ }^{11}$ Their number has varied from 52 in 2009 to 60 in 2010 and to 61 in 2011 indicating the boost of commerce and to 52 in 2016 to indicate the reduction of funds allocated to the promotion of commercial diplomacy due to the Greek economic crisis.

12 This is why the abolition of the section of economic and commercial attachés met with strong resistance and disapproval from Greek sectoral parts of the state and Greek businesses
} 
because the very purpose of their function lies on coordination, cooperation and promotion of close partnership between the MFA, the Greek Chambers of Commerce, the Greek Exports Council, the MNEC, the Ministry of Agriculture, the Ministry of Transport and other productive ministries with which they organise joint business missions (Interview 6, A6-Middle East section, MFA, 2010).

ECOs and their commercial diplomats are in constant communication with different government departments, non-governmental agents and Greek businesses and have learned to play the game of 'building business networks' outside the confines of Greece. Part of their job is to organise business events, conferences and business open days as well as engaging in commercial marketing. The ECOs as a bureaucratic section was also the first section of Greek foreign policy bureaucracy ${ }^{13}$ to introduce process standardisation in the form of ISO 9001:2000 (Interview 5, Commercial Affairs, COREPER, 2009).

ISO 9001, introduced in 2009, aimed at the standardisation of the Greek commercial policy for purposes of ensuring its functional efficiency through yearly scheduled plans on economic and sectoral issues and the standardisation of internal processes for policy planning and implementation. In other words, ISO 9001 was meant to standardise the international commercial policy process and to assess the quality of performance of the ECOs by assessing their output.

The course of developments in performance assessment and foreign economic/commercial policy process standardisation was completed with the launch of the online business portal AGORA ${ }^{14}$. AGORA offers a wide range of information concerning Greek and other economies in the form of research and market reports carried out and uploaded by ECO offices worldwide and in collaboration with the Greek Commercial Chambers, Greek Export Organisations and other bilateral chambers such as the Greek-Arab and the Sino-Greek Chambers of Commerce. The information managed by AGORA is accessible to Greek and foreign public audiences, a step which heralded the start of a new era in the relationship between Greek foreign policy bureaucracy and the public through the use of IT (Interview 7, Economic Diplomacy, B1 MFA, 2009 and 2016). It is for all the above reasons that the section of commercial diplomats is considered to be the most 'outward' and 'up to date' -with regards to economic globalisation, Communication and IT- part of the Greek diplomatic network.

However, despite the added value of commercial diplomats to the Greek diplomatic capital, their performance is sometimes compromised by a general lack of business culture in the MFA. This is the by-product of the ongoing 'Greek security issues' which in practice downgrade the performance of economic and commercial diplomacy whilst prioritising traditional, geopolitical foreign policy concerns. According to MFA economic diplomats, focusing on international economic policy

${ }_{13}$ ISO 9001 was later adopted by Consulates with regards to Schengen processes

${ }^{14}$ AGORA portal, available at \{www.agora.mfa.gr\} 
as their counterparts do for instance in New Zealand or the UK is considered to be luxury (Sitaras, 2005).

For Greek diplomats, preoccupation with national security issues constitutes eighty percent of their job; a fact with tremendous implications for training, orientation and culture (Interview 8, ECO office New York, 2011). Living in the turbulent region of the Balkans and being the only EU country with ongoing and unresolved traditional security issues, translates into a commercial diplomacy which has as a primary objective to strengthen local/regional commercial ties in order to ensure security (security first), (Sitaras, 2005). As a result, the job description of commercial diplomats is still instilled with strong political elements.

Another factor, which poses constraints on the intensification of commercial diplomacy is limited resources. This problem has been exacerbated due to the economic crisis despite the need for more commercial diplomacy as a means of exiting the crisis. Arguably, 'the budget allocated to economic diplomacy is extremely low for a country, which has rendered economic diplomacy the main pillar of its foreign policy'. To illustrate this, the Greek yearly budget for economic/commercial diplomacy in 2009 was $€ 900,000$ for the totality of the 61 ECOs worldwide when for instance Cyprus allocates $€ 700,000$ to their American office alone' (Interview 8, ECO office New York, 2011). This factor alone poses serious hindrances to the effective organisation and operation of Greek commercial diplomacy.

\section{Integrating the Diplomatic Academy's curriculum: a second step towards 'Unification'.}

The Diplomatic Academy, established in 1999 operates as an independent organisational unit of the MFA accountable to the FM. The main objective of the Academy has been to deliver studies and training to MFA's diplomatic candidates. Besides the standard diplomatic education, which is mandatory for all MFA's diplomats (the so-called traditional or political diplomats) the Diplomatic Academy is also responsible for delivering life-long professional training by organising seminars and training courses for all branches of the MFA but also for professionals of other home departments on issues which fall under the competence of international policy (Interview 9, Diplomatic Academy, 2009 and 2015).

The Academy's curriculum was revised by the 2007 MFA Charter reflecting the increasing demands for more effective economic/commercial diplomacy as well as the strategic aim of producing a new breed of diplomats, 'integrated MFA diplomats' to replace the previous two branches of economic specialists (graduates of NSPA) and political diplomats (graduates of the MFA's Diplomatic Academy). The revised curriculum added six monthly compulsory modules in foreign economic affairs in an attempt to start bridging the gap between the political and economic substance of 
foreign policy and therefore between political and commercial diplomats. More specifically, the economic modules are structured as follows (Interview 9, Diplomatic Academy, 2009 and 2015):

a. International and European economic relations - International and Greek Economic Diplomacy

i. International Political Economy and Greek Economic Diplomacy

ii. European Union: Internal Market - Sectoral Policies and Common Trade Policy

iii. Issues of Development Cooperation

b. International Trade System

i. International Trade and Fiscal System

ii. Law of international commerce and trade

iii. Attracting and evaluating business plans

c. Organisation and Operation of ECOs -Principles of International Marketing, Marketing of Greek Exports

d. Special IT applications

i. Advanced Communication Services on the Internet

ii. E-commerce

According to the 2007 MFA Charter, the Diplomatic Academy, as part of its lifelong diplomatic training and continuing education for the MFA's officials, is committed to organise every year a series of seminars on

- Economic Management

- Consular Affairs

- Computing

- Foreign Languages

The newly added subject areas in the Academy's revised curriculum, demonstrate inter alia, a 'redesigned' profile for contemporary Greek diplomats shaped by an intense focus on international economic affairs and trade, marketing and E-services (Passas, 2005: 368). Such developments add a significant economic/commercial dimension to the existing political role of diplomats thus reaffirming Greek governments' strategy to integrate the management of all international policy. To this end, the ultimate objective of the Academy's revised curriculum is to provide the platform whereby an integrated approach to educating diplomats will result into the integrated practice of diplomacy (Interview 9, Diplomatic Academy, 2009 and 2015). 


\section{A step too far? Moving back to a 'Competitive' model?}

Despite triumphant announcements, a wealth of reforms and -at least partlyenthusiasm over the unification of the two branches of diplomacy under the roof of the MFA, the organisational setup of commercial diplomacy proved rather volatile. MFA diplomats dismissed the proposed changes and reforms and ECO diplomats were distraught with the abolition of their bureaucratic sector. In this climate, in 2012, the Greek government resurfaced the issue of re-organising economic and commercial diplomacy on the basis of recommendations made by Task Force for Greece (Task Force Greece report).

Led by Dutch specialists, the Task Force for Greece, is a European Commission administration resource at the disposal of the Greek authorities aimed at addressing the institutional barriers to Greek commerce and exports policy posed by the economic crisis and to provide assistance to Greek authorities in shaping Greece's Export Promotion Strategy (Netherlands Ministry of Economic Affairs, 2012). In the context of this consultation, the team of experts advocated in favour of increasing the focus on commercial diplomacy and business support through a different route. This should be achieved inter alia, by merging commercial and trade activities undertaken by the MFA and the Ministry of Development (MDev) providing for a sustainable infrastructure for collaboration between all stakeholders involved in commercial diplomacy, trade and investment promotion.

Organisationally, this would translate into the transfer of the competence of economic and commercial diplomacy this time to the MDev thus promoting the disintegration of diplomacy into two distinct parts; a political and a commercial. On $9^{\text {th }}$ January 2013, the Minister of Development announced that the competence for commercial diplomacy together with the respective ECOs would be transferred to the MDev. This reform aimed at manning the creation of a new governmental actor, under the aegis of the MDev, focusing on 'outward business orientation' and commerce boosting, which would absorb the existing Greek Organisation of External Trade (Naftemporiki, 2016). Naturally, such institutional initiative, would result in the abolition of the MFA's General Secretariat of International Economic Relations, including the entire structure of the Directorate General B: Economic Affairs (see Appendix I).

The Task Force's proposal was due to the MFA's hitherto observed failure in integrating the two facets of diplomacy and boosting commercial diplomacy outputs. The Dutch report acknowledged the prevalence and persistence of a competitive organisational and professional culture between political and economic/commercial diplomacy functioning at the expense of the intended integration. As a result, the proclaimed 'osmosis' did not reach the expected levels and the diplomatic machine did not make a full contribution to advancement of economic and commercial interests. 
Despite the above recommendation, currently, the competence of commercial diplomacy remains under the aegis of the MFA. According to senior political and commercial officials, 2015 and 2016 have seen this integration model succeeding for the first time, with the MFA's commercial diplomacy outputs increasing. This translates into the MFA's commercial diplomats processing successfully business support requests overseas which have risen from 4,939 in 2007 to 14,964 in 2013 (Interview 10, Business Development, B8, MFA, 2016).

With the moto export or die (Economic and Commercial Offices Memorandum, 2013), commercial diplomats present their position on the future of Greek international policy and diplomacy, which they see as a one way to survival and exiting the economic crisis. To serve this purpose, their value added should be taken into consideration in economic and commercial policy planning in the future and their integration with the MFA should be given time to settle.

\section{Conclusion}

This article explored the under-studied area of Greek commercial diplomacy processes and organisation aiming at contributing to the scholarship of smaller country based studies in commercial diplomacy. The present investigation presented a wealth of primary data demonstrating that Greece follows the patterns observed in developed economies, which have prioritised commercial diplomacy in their foreign policy agenda, re-arranged their foreign ministries and overseas networks of representation to accommodate commercial diplomacy and integrated it in their national diplomatic systems. In this respect, Greece is aligned with mainstream developments in the said area of diplomacy.

The Greek case accords with diplomatic studies literature, in that commercial diplomacy has become a central theme in Greek governments' pursuit of national foreign policy and diplomacy, which is reflected through the re-organisation of the MFA and the mobilisation of the entire diplomatic system, supported by the coherent MFA reform package of 2007. By raising commercial diplomacy to one of their most important and urgent MFA function, Greek governments demonstrate that they are in search of the optimum strategy to responding to the era of commerce without borders, on which national prosperity depends whilst at the same time, they are seeking a viable external policy to boost national economy. This, inter alia, provides evidence of a re-conceptualised Greek national interest, beyond traditional security geopolitical concerns which focuses on boosting Greek exports and supporting Greek entrepreneurship overseas.

In the reconceptualization of Greek national interests lies the realisation that the overseas diplomatic network can be a driver to boosting Greek economy and commerce, expanding markets and attracting inward investments and simultaneously, increasing national income and aiding in overcoming the economic 
crisis. It was such realisations that drove reforms towards an 'integrated model' for Greek diplomacy and a modernised MFA organised along the principle of functionality presented in Appendix I. It is important to note however, that such dramatic shift of emphasis towards commercial diplomacy met with resistance not only by traditional political diplomats but also by the fact that unlike in other strong economies, in the Greek case political diplomacy revolving around issues of geopolitical security has never taken the back seat to allow prominence to commercial diplomacy.

Therefore, in terms of contextualising the Greek case in the widest commercial diplomacy literature, it can be argued that at most part it is aligned with strong Western economies demonstrating elements of Rana's Unification model. This means that Greece, similarly to Australia, Canada, Sweden and other big economies has unified the political and economic/commercial diplomatic competences and integrated them within the MFA. In organisational terms this has been materialised with the addition of a separate commercial/export promotion unit, in this case the ECOs and Directorate General B' to the traditional diplomatic service structure in the MFA.

At the same time however, it also demonstrates elements of the 'Competition model' which reflects mostly organisational setups in developing countries such as India and Thailand, where the foreign ministry and economic or other ministries engage in turf battles over responsibility of export promotion and commercial diplomacy. The consequence of such battles, with the added domination of traditional political diplomacy culture is that the diplomatic machine does not make a full contribution to the promotion and execution of a coherent commercial diplomatic strategy. This has been the case with the ECOs and commercial diplomats which have been a 'nomadic' branch of Greek diplomacy, moving from the Ministry of Trade to the Ministry of Economy in the 1990s, then to the MFA in early 2000 and possibly to the Ministry of Development at the close of this decade. Therefore, in the spectrum ranging between integrated commercial diplomacy or else the 'Unification model' and fragmented commercial diplomacy or else the 'Competition model', the Greek case tilts more towards the former but still oscillates between the two. 


\section{LIST OF REFERENCES}

AGORA portal, available at \{http://agora.mfa.gr/frontoffice/portal.asp?cpage=NODE\&cnode=64\&clang=1\} accessed 17.01.11.

Bakoyianni, D. (2009). 'Greek Foreign Minister's Address on the New Online Services of the MFA for the Support of the Business Community and Civil Society'. Athens: MFA Reports.

Bakoyianni, D. (2009b). 'Speech: Greece Reaching Global Markets: International Meeting on Food and Beverages'. available at \{http://www.mfa.gr/www.mfa.gr/GoToPrintable.aspx?UICulture=elGR\&GUID=\%7BA2006D1F-B587-4D21-8D1D-60FAC623ACBC\%7D\} accessed 08/26, 2010.

Bayne, N. and Woolcock, S. (2003). The New Economic Diplomacy: Decision making and negotiation in international economic relations. Ashgate.

Berrige G.R. and James, A. (2001). A Dictionary of Diplomacy. Basingstoke: Palgrave.

Calof, Johnathan and Beamish, Paul, W. 'Adapting to Foreign Markets: Explaining Internationalisation' International Business Review, 4(2), pp. 115-131.

Coolsaet, R. (2004). 'Trade and Diplomacy: The Belgian Case', International Studies Perspectives, 5, pp 61-65

Economic and Commercial Offices. (2013). Memorandum for the attention of commercial diplomats titled: 'The position of ECO offices in the Greece of 2013'. Athens, Ministry of Foreign Affairs.

Frontini, A. (18 September 2013). Advancing a multi-level system of European commercial diplomacy: is there a role for the EU?'. Policy Brief, European Policy Centre.

Georgiadou, E. (2013). The Greek Ministry of Foreign Affairs in the Transforming World Politics: Between Isomorphism and Path Dependence. The Hague Journal of Diplomacy 8(2), pp139-160.

'Go-International Economic Cooperation Programme' available at $\{\mathrm{http}: / / g 0-$ international.gr/\} accessed 19.05.2015

Karabarbounis, C. (2007). 'Via the diplomatic route: The historical and institutional framework of the formation of the Greek Ministry of Foreign Affairs' [in Greek]. Athens, Sideris. 
Kostecki, M. and Naray, O. (2007). Commercial diplomacy and international business, Discussion Papers in Diplomacy, No. 107. Netherlands Institute of International Relations, 'Clingendael'.

Kurbalija, J. (1999). Diplomacy in the Age of Information Technology In Melissen, J. (Eds.), Innovation in Diplomatic Practice, 171-197, Basingstoke, MacMillan Press.

Lee, D. (2004). The Growing Influence of Business in U.K. Diplomacy, International Studies Perspectives, 5, pp50-54.

Lee, D. and Hudson, D. (2004). The old and new significance of political economy in diplomacy. Review of International Studies, 30, pp343-360.

Mercier, A. (2007). Commercial Diplomacy in Advanced Industrial States: Canada, the UK and the US'. Discussion Papers in Diplomacy. Netherlands Institute of International Relations, 'Clingendael'.

Netherlands Ministry of Economic Affairs, Netherlands Domain Leader, (2012) Report: A Trade Promotion Strategy for Greece, (The Hague), available at \{http://sev4enterprise.org.gr/wp-content/uploads/2014/05/TELONEIA-1.pdf\} accessed 06.03.2015

Naftemporiki.gr, Attracting investment in a given time frame, available at \{http://l.naftemporiki.gr/news/cstory.asp?id=2270786\} accessed 18.05.2016.

Naray, O. (2008). Commercial Diplomacy: A Conceptual Overview, paper presented in the $7^{\text {th }}$ World Conference of TPOs - The Hague, The Netherlands, 2008.

Naray, O. (2012). 'Commercial diplomacy: an integrative framework. International Journal of Diplomacy and Economy, 2:1, pp.119-133.

Passas, A. (2005). The Greek Ministry of Foreign Affairs in the Transforming European Union Institutional and Political System [in Greek], In Arvanitopoulos, K. and Koppa, M. (Eds.), Thirty years of Greek Foreign Policy: 1974-2004, 356-376. Athens, Livanis Publications

Penev. S., Udovič, B. and Dukič, M. (2014). 'Commercial Diplomacy in Serbia: Characteristics and areas for improvement'. Economic Themes. 52:3 (2014), pp263-280.

Potter, E.H. (2004). Branding Canada: The Renaissance of Canada's Commercial Diplomacy. International Studies Perspectives, 5, pp55-60.

Presidential Decree, 159/2002

Rana, K.S. (2000). Economics in Command, In Inside Diplomacy, Chapter 4: 96-127. Manas Publications. 
Rana, K.R. (2004), Economic Diplomacy in India: A Practitioner Perspective, International Studies Perspectives, 5, pp66-70.

Rana, K.S. (2007). Economics and Diplomacy, In Bilateral Diplomacy, Chapter 4: 67-78. DiploFoundation.

Ruël, H., De Boer, S. and Ten Haaf, W. (2013). Commercial diplomacy in practice: experiences of international business executives and representatives in Malaysia. International Journal of Diplomacy and Economy, 1:3/4, pp. 258-273.

Ruël H. and Zuidema , L. (2012). The effectiveness of commercial diplomacy: A survey among Dutch embassies and consulates, Discussion Papers in Diplomacy, No. 123. Netherlands Institute of International Relations, 'Clingendael'.

Sir Sanders, R. (2010) Delivering economic good: a new role for diplomacy, Caribbean News Online, available at:

\{http://www.jamaicaobserver.com/columns/Delivering-economic-good-a-new-rolefor-diplomacy 7858291\} accessed 15.10.2010.

Sitaras, V. (2005, July/September). Demarcating the competence of diplomats and trade attachés.

Rixikelefthon Quarterly Review for Administrative Reform [in Greek], pp10-20.

Task Force for Gr eece report, available at $\{$ http://ec.europa.eu/about/taskforcegreece/index_en.htm\} accessed 18.05.2016

Tsardanidis, C. and Mysiri, E. (2013). The reconstruction of Greek economic diplomacy. Foreign Affairs, 18(2), pp85-105. [The Hellenic Edition: In Greek]

US Department of State report, America's Overseas Presence in the 21st Century, 1999, p: 28, available at https://fas.org/irp/threat/rpt-9911 opap.pdf, accessed $19 / 05 / 2016$

Visser, R. and Ruël, H.J.M. (2014). Innovation in International Business Support: a research agenda for commercial diplomacy. International Journal of Diplomacy and Economy, 2:3, pp. 238-257.

Zuidema, L. and Ruël, H. (2012). The Effectiveness of Commercial Diplomacy: A Survey Among Embassies and Consulates. In Huub Ruël (eds) ,Commercial Diplomacy in International Entrepreneurship: A Conceptual and Empirical Exploration, (Emerald Group Publishing Limited), pp.105-139. 


\section{RESEARCH INTERVIEWS}

Interview 1, Director of Geographic Policy and Strategic Planning, YDAS-DG International Development Cooperation, MFA, Athens, 2008

Interview 2, Brigadier Director of International Relations Unit, Ministry of Defence, Former Greek Representative to the CFSP, (Athens: MFA, 11.12.2009); Interview with the General Consul to London, Greek General Consulate, (London: Greek Embassy, 7.12.2010).

Interview 3 Advisor for Economic and Commercial Affairs at the Economic and Financial Policy Unit of the Permanent Representation of Greece to the EU, (Brussels, Greek Representation to the EU, 01.02.2010)

Interview 4, Director of General Directorate B8 for Business Development, (Athens: MFA, 04.12.2009).

Interview 5, Head of Economic and Commercial Affairs, Economic and Commercial Office, COPEPER, (Brussels, 3.02.2009).

Interview 6, Embassy Councillor in Directorate General A6 for economic affairs with Arabic States and the Middle East, (Athens: MFA, 07.12.2010).

Interview 7, Director of General Directorate B1 of Strategic Planning and Economic Diplomacy, (Athens: MFA, 03.12.2009 and 20.04.2016).

Interview 8, Head of Economic and Commercial Office, (New York, 18.10. 2011). Interview 9, Director of the MFA Diplomatic Academy, (Athens: MFA, 15.12.2009 and 20.07.2015).

Interview 10,Director of General Directorate B8 for Business Development, (Athens: MFA, 30.03.2016). 


\section{Appendix I}

\section{The Greek Ministry of Foreign Affairs}

Chart published by Elena Georgiadou, 'The Greek Ministry of Foreign Affairs in the Transforming World Politics: Between Isomorphism and Path Dependence', The Hague Journal of Diplomacy (2013) 8 (2), pp. 139-160

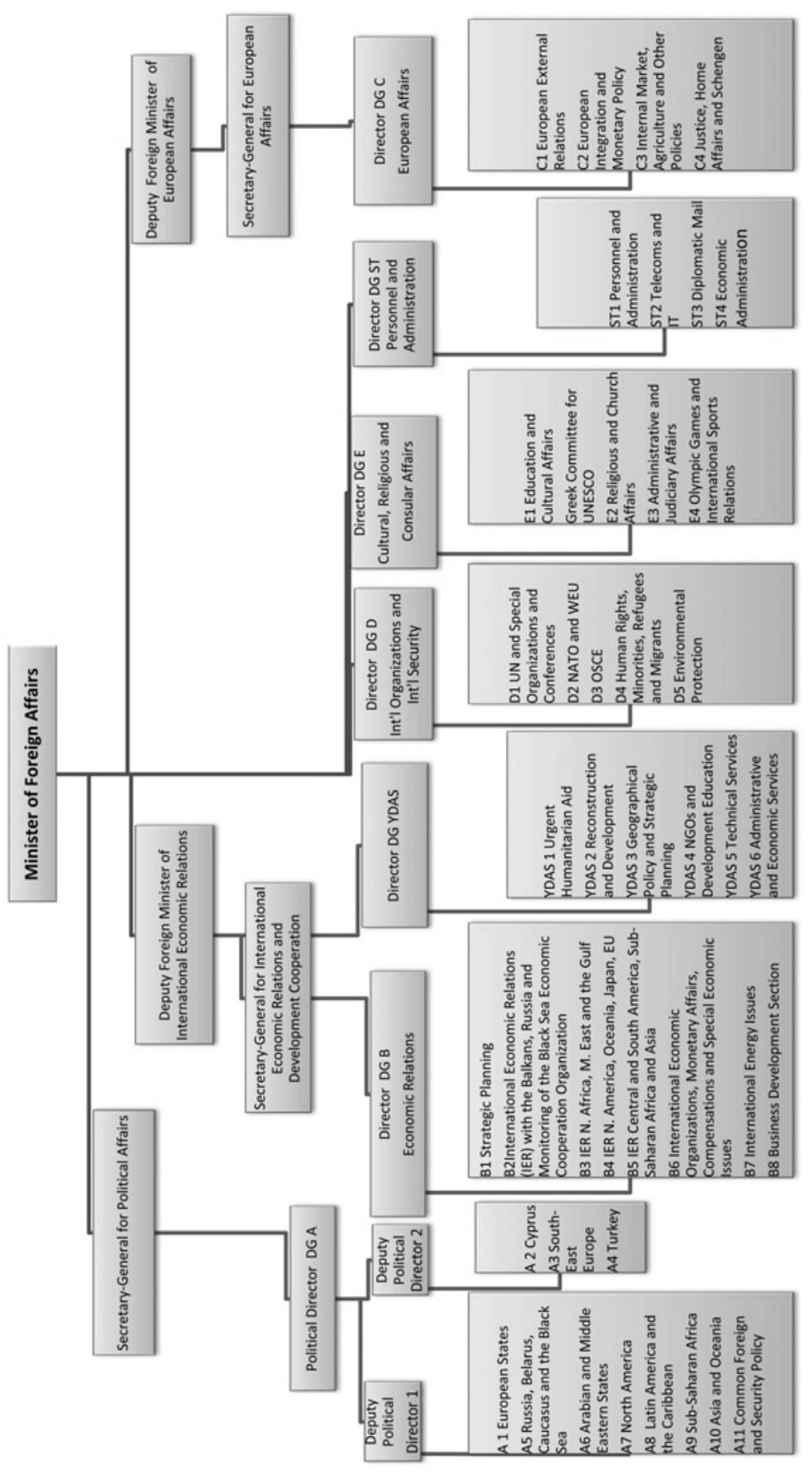


